\title{
Collaborative writing revision process among learners of English as a foreign language (EFL) in an online community of practice (CoP)
}

\author{
Norizan Abdul Razak, Murad Abdu Saeed \\ Universiti Kebangsaan Malaysia, Malaysia
}

\begin{abstract}
This qualitative study aimed to identify the revision strategies among learners of English as a foreign language (EFL). It also examined the focus of these strategies and learners' participation and membership in an online community of practice $(\mathrm{CoP})$. As part of shared practices in this online CoP via a Facebook group, these revision writing activities were carried out among a heterogonous group of 15 EFL learners from different EFL countries. Data was collected from the learners' original and revised paragraphs, online interactional exchanges and responses to the post-revision discussions. The qualitative analysis of the data revealed that addition, substitution, deletion, permutation (re-organizing elements), consolidation (combining elements), distribution (breaking up combined elements), negotiation and reciprocal scaffolding are the main revision strategies. These revision strategies focused on writing mechanics, language (form and meaning), unity and content of paragraphs. The CoP facilitated students' revision process by increasing the participation of those peripheral learners (new members) in these activities through social ties and relationship building, a supportive learning environment and developing a sense of autonomy among them. These findings have underlying several theoretical, pedagogical and research implications and have provided a deeper insight into utilization of Facebook groups as CoPs conducive to useful writing revision activities.
\end{abstract}

\section{Introduction}

Writing instruction in English as a second language (ESL) and English as a foreign language (EFL) has shifted from viewing writing as a product to writing as a process, comprising planning, drafting, and revising (Faigley \& Witte, 1981). As an essential part of the writing process approach, writing reviewing/revision has been paid extensive attention by instructors and researchers, especially in the ESL context. Previous studies indicated how revision activities assist ESL/EFL learners to improve their writing skills (Lam, 2010; Min, 2006; Rollinson, 2005). However, involving EFL learners in collaborative revision in which they can incorporate instructors' and peers' written comments into their revised texts is still challenged by the environment and time constraints of the physical classroom (Lam, 2010).

Recently, there has been an increase in the application of social networking services (SNSs) and Web 2.0 to ESL/EFL writing instruction. These technologies facilitate learners' interaction and collaboration in writing (Elola \& Oskoz, 2010; Kessler, Bikowski, \& Boggs, 2012). Yet, most of these findings were based on revision activities as part of regular writing courses prescribed at colleges rather than out-ofclassroom writing activities that can stand on their own. Additional time in writing revision is important, especially for those learners struggling with the language (Horning \& Becker, 2006). Moreover, while most of these previous studies examined collaborative writing revision activities through a Wiki, only a few studies investigated the ESL/EFL learners' writing through Facebook (Haverback, 2009; Shih, 2011; Yunnus, Salehi, Huisun, \& Yen, 2011). Therefore, in an attempt to address these gaps in previous research, this study investigated collaborative writing revision activities among EFL learners in a community of practice (CoP) via a Facebook group.

\section{Literature review}

Recent research has pointed to the potential of SNSs and Web 2.0 technologies in engaging ESL/EFL learners in the process of writing and assisting them to attend to their final products through collaborative revision. Many researchers (Berbache, 2007; Horne, 2011; Kessler, 2009; Woo, Chu, Ho, \& Li, 2011) have found various revision strategies or operations; addition, substitution, deletion, permutation (arranging elements), consolidation (combining elements) and distribution (breaking up combined elements) used by ESL/EFL learners. Other revision strategies are scaffolding (Santoso, 2010), meaning 
negotiation and content discussion (Liang, 2010). Moreover, most of these studies indicate that writing revision via SNSs helps learners to attend to local aspects related to grammar, accuracy and fluency (producing more words in their revised texts), while a few of them reported how learners could focus on global aspects of written texts including content, organization and cohesion (Alshumaimeri, 2011). Despite the evidence of the role of writing revision activities via technological tools in combination with pedagogical practices in facilitating ESL/EFL learners' interaction and development in writing, these studies have not paid attention to the social aspects of learning from the perspective of the theory of CoP posited by Lave and Wenger (1991). This indicates that the potential of these SNSs in collaborative writing revision needs to be adequately explored from another theoretical and pedagogical perspective that emphasizes the various aspects of situated learning or community of learners.

Regarding the role of Facebook in facilitating ESL/EFL learners' learning, especially at university levels, studies emphasized that by using Facebook, learners can create new groups or join existing ones as online communities (Boyd \& Ellison, 2011; Razak, Saeed, \& Ahmad, 2013). They can also observe the activities in these groups to which they belong through the track feature (Lampe, Wohn, Vitak, Ellison, \&Wash, 2011). Learners can also engage in creating learning content and sharing it with a potentially global audience (Duffy, 2011). Another feature of Facebook is the commenting facility through which learners can comment on one another's post. Being integrated in classroom-based courses, Facebook can assist ESL learners in their writing process (Haverback, 2009; Majid, Stapa, \&Keong, 2012; Shih, 2011). There is also an extensive use of Facebook among learners as part of their out-of-campus or university practice of English (McCarthy, 2013;VanDoorn \& Eklund, 2013). Facebook enables EFL learners not only to learn that language but also its culture (Mitchell, 2012). Yet, there are several aspects of weaknesses of such SNSs including learners' gradually diminished participation and control of their learning (Grandzol \& Grandzol, 2010), distraction caused by many other posts and comments irrelevant to learning, and learners' tendency to use short forms and abbreviations that might affect their writing (Yunnus et al., 2012). This suggests that learners' use of Facebook for learning will not ensure effective learning without instructors' facilitation and other peers' support in the learning activities. Therefore, the recent call for more insightful investigation of SNSs such as Facebook from the participants' contributions to these communities suggests the importance of exploring how online learners, especially those who are still new members, describe their learning experience from the perspective of their membership level after a period of time.

\section{The study}

\section{Conceptual model of collaborative writing revision in a Facebook CoP}

In conducting this research, the collaborative writing revision activities were designed and implemented in the Only For English Learning CoP, a Facebook group developed by the researchers and several EFL instructors. The current conceptual model of collaborative writing revision as illustrated in Figure 1 is informed by three major learning theories: Vygotsky's (1978) social development theory or social learning theory, Lave and Wenger's (1991) situated learning theory or theory of CoP and the social perspective of writing revision as a process (Faigley, 1986; Tompkins, 2008). It also illustrates how these theories were conceptualized as the bases for the pedagogical and methodological aspects of the present research including the writing revision activities and how they were carried out and investigated.

Thus, central to the social development theory (Vygotsky 1978) is scaffolding or assistance offered by teachers or more capable peers to less capable learners to reach a particular level of learning (Santoso, 2010). Findings of previous studies indicated that those more knowledgeable learners can also learn from their less skilled peers through interaction and collaboration (Duff, 2007).

Since the concept of community is central to the present study, the framework proposed integrates the CoP theory (Lave \& Wenger, 1991). Like Vygotsky's (1978) learning theory, this theory assumes that engaging learners in meaningful learning practices plays an important role in the learning process and knowledge construction. It also characterizes learning in a $\mathrm{CoP}$ as a dynamic process of participation. In their initial stage of participation in a given community, learners are relatively peripheral. This group is labelled as peripheral members (those who still observe the practices of other members). However, as they learn the practices and activities of the community, they become active members, but not as intensely 
as the core group members. Within time, those active members become the core, the group representing the centre of any CoP (Lave \& Wenger, 1991). Therefore, according to Lave and Wenger, an interactive learning environment is that environment where peripheral members are provided with the opportunities to observe, learn and get involved in useful practices that enable them to move into more legitimate participation in the community. This theory also emphasizes how members' sense of identity is fostered by their sense of belonging or becoming a part of that CoP. This means that a learner's identity is not only shaped by the meaning attached to an activity that is practiced in the community, but it is also shaped by his/her relationship to other members and the community itself (Wenger, 1998).

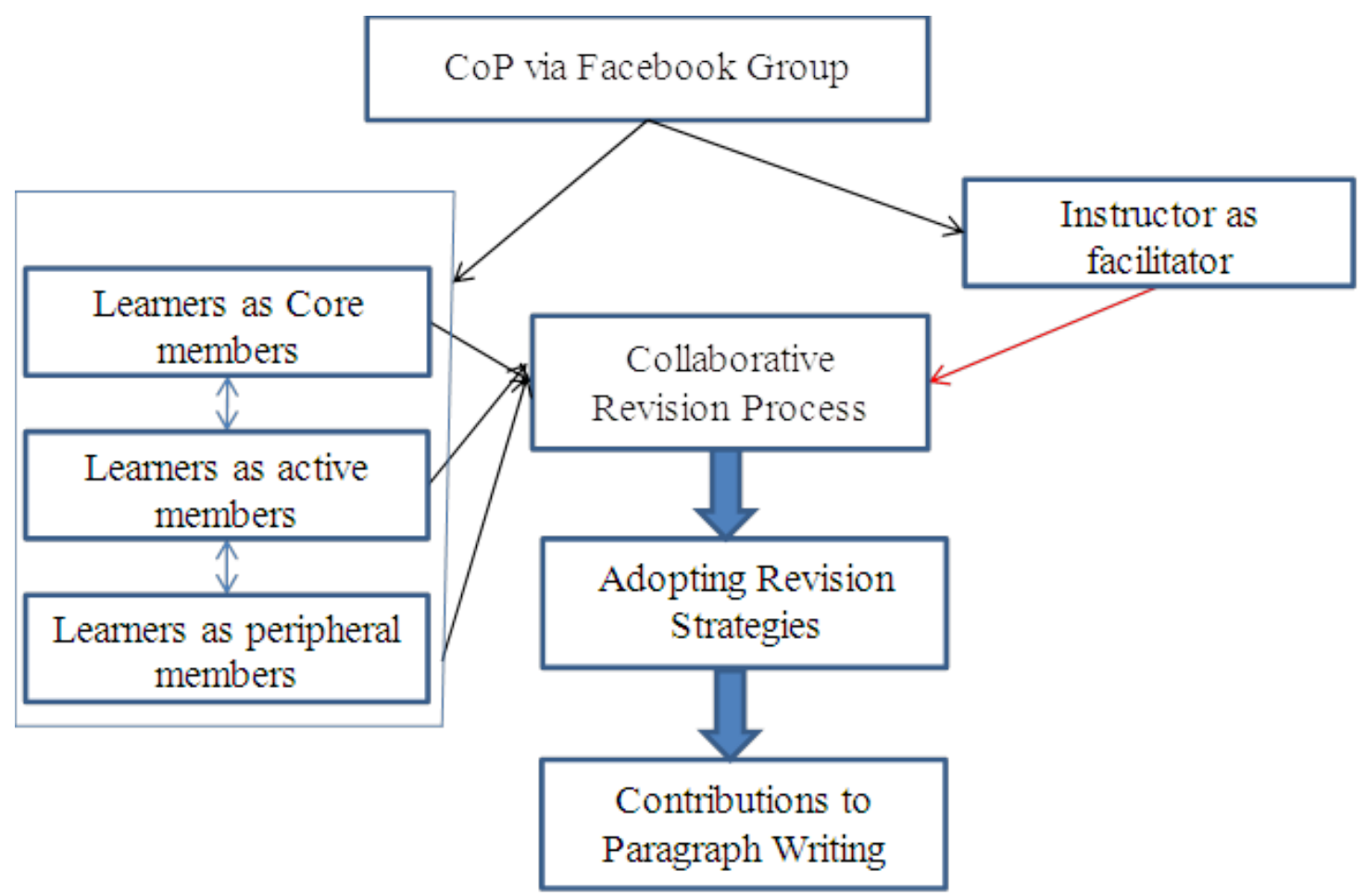

Figure 1.Conceptual model of collaborative writing revision in a $\mathrm{CoP}$

The social perspective of the writing process assumes that revising is an ongoing, recursive, problemsolving process. It is not restricted to the post-writing stage but it can be at all stages of the writing process. In this sense, it is a dynamic process (Faigley\& Witte, 1981; Sommers, 1996). Learners' ability to revise their texts is important since it assists them to reshape their thoughts and ideas, discover and reconstruct meaning, and enhance their texts (Reynolds \& Bonk, 1996). Thus, the social view of the writing process places an emphasis on the central role of revision in both the process and outcome of writing development. This implies that when learners are involved in effective writing revision activities, they adopt various strategies to enhance their products or written texts. The current model was constructed based on a negotiation between the researchers and the instructors in the online CoP. Participants with different levels of membership in the community and levels of English were allocated to one group, since these revision activities were part of shared practices in this online CoP. The CoP instructor facilitated their collaborative discussions and intervened by providing scaffolds when necessary. Further details about the conceptualization of the CoP, especially the three levels of membership are provided in the Methodology section. 


\section{Research questions}

The current study, in investigating EFL learners' collaborative writing revision activities in a CoP via a Facebook group, aimed to provide answers to these research questions:

(1) What types of strategies or operations do the EFL learners adopt in revising their paragraphs in writing skill in this CoP?

(2) How do the EFL learners' collaborative writing revision activities contribute to their paragraph writing?

(3) How do the EFL peripheral members verbalize their participation and membership in this CoP in relation to the collaborative writing revision activities?

\section{Research context}

\section{The Only For English Learning CoP}

The study reflects conceptualization of the CoP especially in selecting this Only For English Learning $\mathrm{CoP}$ and the sampling process. Thus, based on the basic three dimensions of determining a CoP offered by Wenger (1998), which were conceptualized by Pearce (2010), this CoP was observed to meet these dimensions (Table 1). First, The Only for English Learning CoP as shown in Figure 2 is a Facebook group which was developed as a joint effort between three EFL lecturers and the researchers in June 2011. It was developed for the purpose of providing EFL learners with an out-of-classroom space where they can use and practice English outside the university context. Since its development, this CoP has attracted many EFL learners from different Asian and Arabic countries. The number of the members reached 22,947 by March 15, 2013.

Table 1

Observation of Wenger's (1998) basic dimensions of a CoP in the Only For English Learning CoP

\begin{tabular}{|c|c|c|}
\hline $\begin{array}{l}\text { Wenger's (1998) } \\
\text { basic dimensions }\end{array}$ & Definitions & Observation of the Only For English Learning CoP \\
\hline Joint enterprise & $\begin{array}{l}\text { What it is about as } \\
\text { understood and } \\
\text { continually regenerated by } \\
\text { its members }\end{array}$ & - Negotiated enterprise (Practicing English) \\
\hline $\begin{array}{l}\text { Mutual } \\
\text { engagement }\end{array}$ & $\begin{array}{l}\text { How it functions or binds } \\
\text { members together }\end{array}$ & $\begin{array}{l}\text { - Engaged diversity } \\
\text { - Relationship building } \\
\text { - Sharing } \\
\text { - Communicating }\end{array}$ \\
\hline Shared repertoire & $\begin{array}{l}\text { What communal resources } \\
\text { members have developed }\end{array}$ & $\begin{array}{l}\text { - The Facebook Group } \\
\text { - The Facebook Page } \\
\text { - The Forum } \\
\text { - The Wiki Collaborative Writing Community } \\
\text { - English for Communication }\end{array}$ \\
\hline
\end{tabular}

The learners, as members of this CoP, are involved in useful posts and activities in listening, reading, grammar, vocabulary and writing provided by the instructors daily. They are also engaged in dynamic discussions on social aspects, issues and challenges in English, communication, socialization and relationship building activities. One can observe examples of shared repertoire such as the chat tools, the Facebook page and forum and the Wiki Collaborative Writing Community, which are also shared through links in the group discussions so as to provide new members with information about the shared goals and practices (Figure 3). But this shared repertoire can also be non-physical, such as the methodology learners negotiate to accomplish the set of activities. In this sense, the members of this CoP use only English as their means for carrying out their shared practices, fulfilling their activities, negotiating meaning and communicating with one another. 


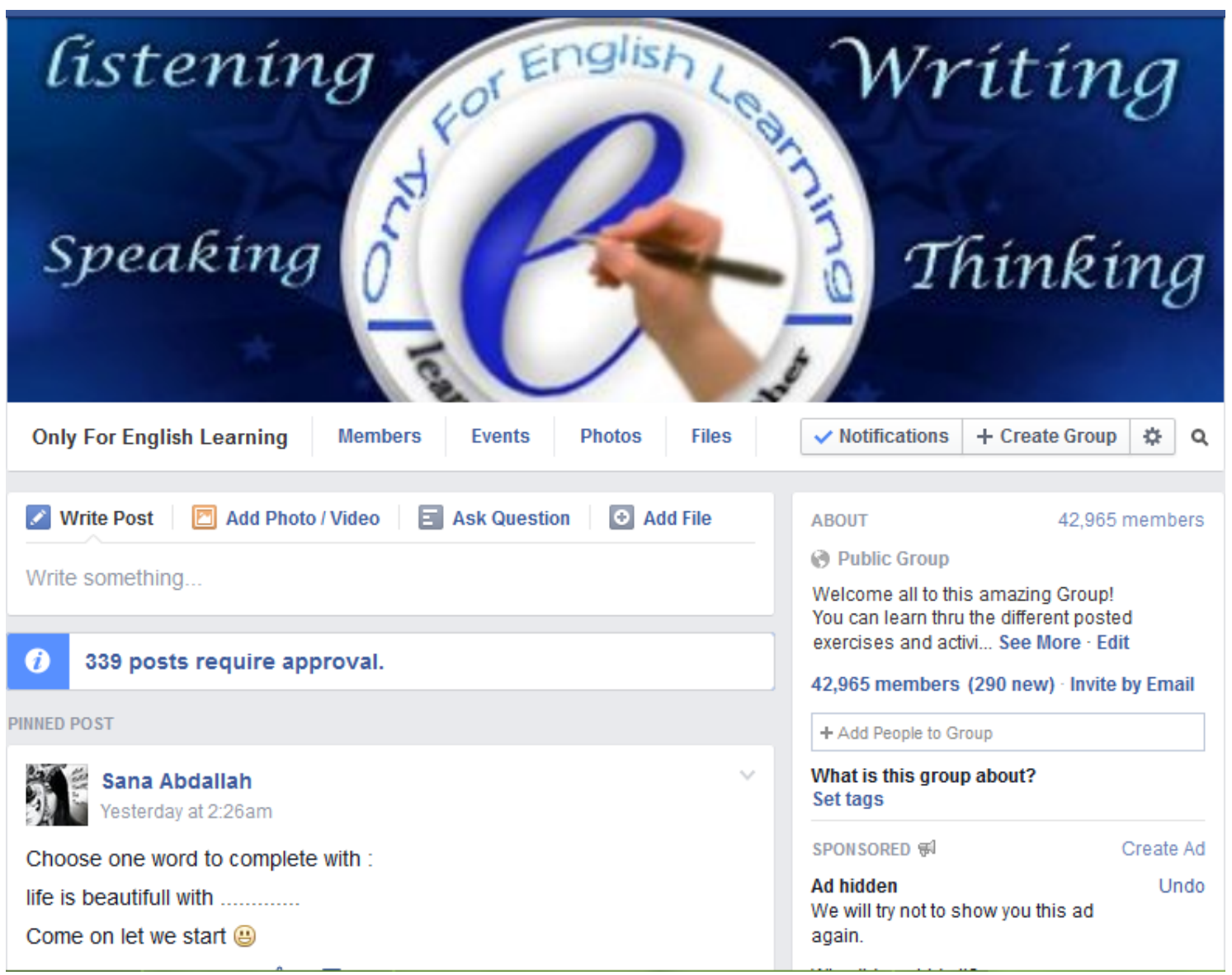

Figure 2.The Only for English Learning CoP via the Facebook

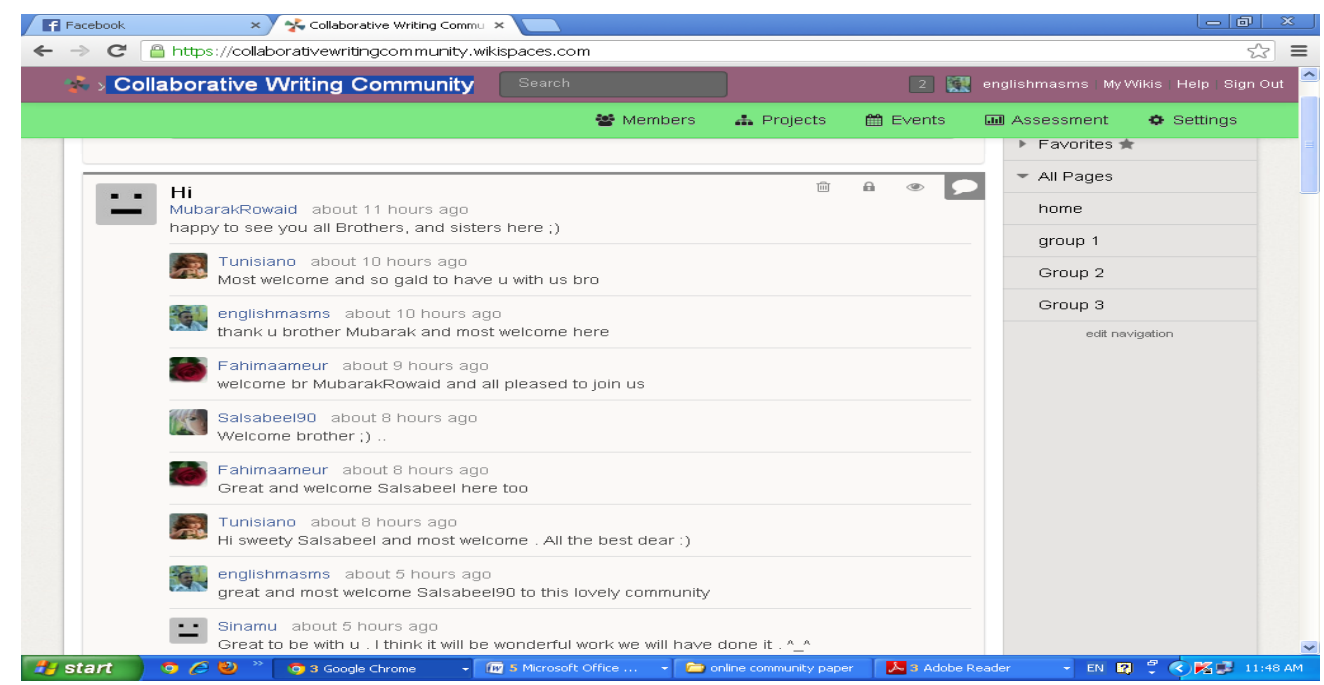

Figure 3.The Wiki Collaborative Writing Community 


\section{Participants}

A purposeful sampling aiming to seek certain criteria or characteristics in the samples, which can be preinformed by certain theories, (Bogdan\&Biklen, 2007) was adopted in this study. The first criterion is the variation among learners in terms of their English language skill level. All the learners participating in this study were second- and third-level students of English at university. Such sampling, aimed at selecting participants with these two levels, was based on the notion of scaffolding and assistance provided by more capable learners to those less capable peers. This was evident by the findings of several empirical studies on ESL collaborative writing (Brooks, 2010; Maftoon \& Ghafoori, 2009; Yu \& Choe, 2011) among heterogeneous groups.

Regarding the second criterion, conceptualizing the levels of membership as advocated by the theory of $\mathrm{CoP}$ in determining the levels of membership among learners in online communities has been reported to be challenging. In conceptualizing the definitions of the three groups (periphery, active and core as offered by this theory to determine online communities), several researchers used quantitative measures of learners' participation as shown in Table 2.

Table 2

Criteria for determining the levels of membership in a CoP

\begin{tabular}{ll}
\hline CoP membership levels & Wenger's(1998) definitions \\
\hline Periphery & Members that keep to the sidelines watching the interaction \\
Active & Occasional participation but not as much as the core group \\
Core group & $\begin{array}{l}\text { Active participants in the community } \\
\text { 1. Post intensity= Number of members' posts in the community }\end{array}$ \\
2. Willingness to extend participation= Number of members' \\
comments in the community's posts \\
3asko \& Teigland, 2002) $\begin{array}{l}\text { 3. Contribution to the community= Number of comments these posts } \\
\text { generated }\end{array}$ \\
$\begin{array}{l}\text { 4. Date of joining the community } \\
\text { 5. Patterns of behaviour observed in grammar discussions }\end{array}$
\end{tabular}

Thus, in this study, the same qualitative measure of the post intensity, participants' willingness to extend participation and contributions of these posts to the community was used by counting the number of posts, participants' comments and comments generated by these posts for the last three months prior to announcement of the writing revision activities (Table 3). However, since some recent studies have pointed out that simply counting the number of learners' posts in online communities when researching online learners 'participation is not sufficient, we added the joining date of each member and reflected upon the patterns of some members' participation behaviour and role in a series of weekly grammar discussions carried out in the community, in order not to juxtapose the active with core members. Based on this, the participants in this study were 15 EFL university students (13 females and 2 males) who are members of The Only for English Learning CoP. They represent a heterogeneous group in terms of their backgrounds, gender, level of English at college and level of membership in this CoP. 
Table 3

Profile of the samples in the current study

\begin{tabular}{|c|c|c|c|c|c|c|c|c|}
\hline ID & Country & Gender & $\begin{array}{l}\text { No. of } \\
\text { participant } \\
\text { posts }\end{array}$ & $\begin{array}{c}\text { No. of } \\
\text { participant } \\
\text { comments }\end{array}$ & $\begin{array}{c}\text { No. of } \\
\text { comments } \\
\text { generated }\end{array}$ & $\begin{array}{c}\text { Joining } \\
\text { date }\end{array}$ & $\begin{array}{l}\text { Observed } \\
\text { patterns of } \\
\text { behaviour }\end{array}$ & $\begin{array}{l}\text { Level of } \\
\text { mem'ship }\end{array}$ \\
\hline $\mathrm{S} 1$ & Sudan & $\mathrm{F}$ & 24 & 233 & 635 & $\begin{array}{c}\text { Over a } \\
\text { year ago }\end{array}$ & Initiator & Core \\
\hline $\mathrm{S} 2$ & Syria & $\mathrm{F}$ & 23 & 217 & 502 & $\begin{array}{l}\text { Over a } \\
\text { year ago }\end{array}$ & Initiator & Core \\
\hline $\mathrm{S} 3$ & Yemen & $\mathrm{F}$ & 0 & 179 & 0 & $\begin{array}{c}6 \text { months } \\
\text { ago }\end{array}$ & & Active \\
\hline $\mathrm{S} 4$ & Algeria & $\mathrm{F}$ & 8 & 112 & 103 & $\begin{array}{c}5 \text { months } \\
\text { ago }\end{array}$ & & Active \\
\hline S5 & Algeria & $\mathrm{F}$ & 4 & 108 & 26 & $\begin{array}{c}4 \text { months } \\
\text { ago }\end{array}$ & & Active \\
\hline S6 & Tunisia & $\mathrm{F}$ & 18 & 256 & 823 & $\begin{array}{l}\text { Over a } \\
\text { year ago }\end{array}$ & Initiator & Core \\
\hline S7 & Egypt & $\mathrm{F}$ & 27 & 202 & 547 & $\begin{array}{c}\text { Over a } \\
\text { year ago }\end{array}$ & Initiator & Core \\
\hline $\mathrm{S} 8$ & Yemen & M & 0 & 6 & 0 & $\begin{array}{c}6 \text { days } \\
\text { ago }\end{array}$ & & Peripheral \\
\hline S9 & Philippines & $\mathrm{F}$ & 26 & 207 & 603 & $\begin{array}{l}\text { Over a } \\
\text { year ago }\end{array}$ & Initiator & Core \\
\hline S10 & Yemen & M & 0 & 9 & 0 & $\begin{array}{c}7 \text { days } \\
\text { ago }\end{array}$ & & Peripheral \\
\hline S11 & Yemen & $\mathrm{F}$ & 9 & 117 & 203 & $\begin{array}{c}7 \text { months } \\
\text { ago }\end{array}$ & & Active \\
\hline $\mathrm{S} 12$ & Algeria & $\mathrm{F}$ & 6 & 219 & 102 & $\begin{array}{c}5 \text { months } \\
\text { ago }\end{array}$ & & Active \\
\hline $\mathrm{S} 13$ & Yemen & $\mathrm{F}$ & 0 & 2 & 0 & $\begin{array}{c}4 \text { days } \\
\text { ago }\end{array}$ & & Peripheral \\
\hline S14 & Tunisia & $\mathrm{F}$ & 1 & 8 & 16 & $\begin{array}{l}9 \text { days } \\
\text { ago }\end{array}$ & & Peripheral \\
\hline S15 & Yemen & $\mathrm{F}$ & 0 & 4 & 0 & $\begin{array}{l}11 \text { days } \\
\text { ago }\end{array}$ & & Peripheral \\
\hline
\end{tabular}

\section{Learning design}

For the writing revision activities, the Only For English Forum created by the core members as shown in Figure 4 was connected to the Facebook group so that any new post in the forum could be published in the Facebook CoP as a way to help the learners not to get distracted by many other daily posts in the community. This was also utilized for the writing revision activities to make these activities easily tracked by the respondents, since they are distinguished from other activities or posts in the same CoP. 


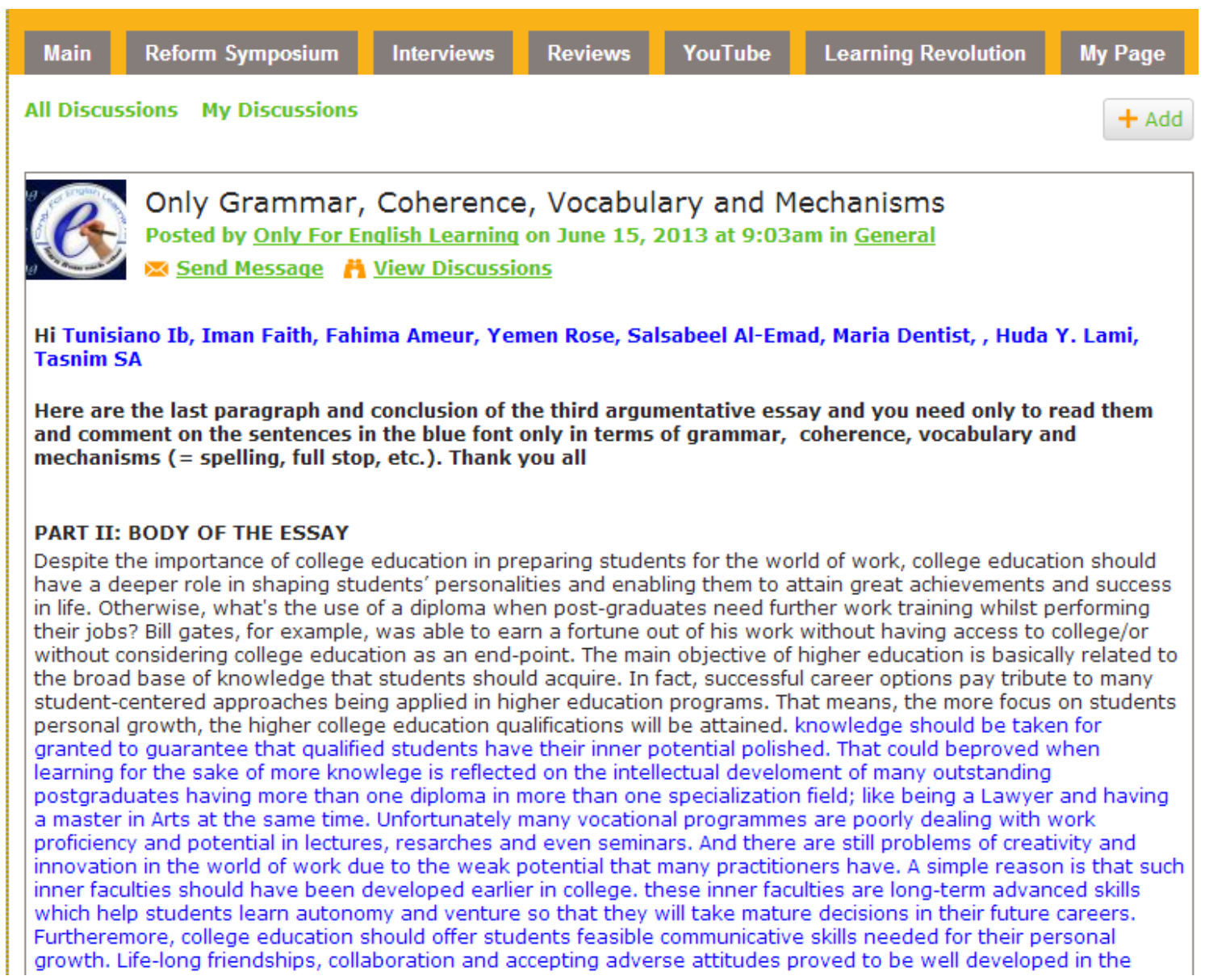

\section{Figure 4. The Only For English Forum}

In the first week, the instructor announced the activities along with the ID names of those 15 EFL learners who were members of the online CoP. The selected participants showed their willingness to attend all collaborative writing discussions, since they joined this CoP for the purpose of enhancing their English skills, especially their written skills. They were also requested to provide suggestions for scheduling the collaborative writing activities. It was decided that the activities would be carried out in several sessions. Then, the instructor instructed them on how to write a paragraph in English. Following this, the EFL learners were assigned to individual writing. They wrote paragraphs on a topic of their own choice in free writing. After submission, the instructor announced the collaborative writing revision activities according to a schedule that they had already fixed. Thus, this study covered 10 sessions of collaborative writing activities in which the participants revised eight paragraphs in the Only for English Learning CoP.

\section{Methodology}

\section{Research design}

This study adopted an exploratory qualitative approach to data collection and analysis for several reasons. First, this type of qualitative research design focuses on describing and understanding a phenomenon (Cresswell, 2008). In the case of the present study, the focus was on describing the collaborative writing process as situated in an online CoP. Secondly, the exploratory qualitative research design is concerned with dynamics and processes rather than outcomes measured by scores. Therefore, the present study aimed to explore the EFL learners' dynamics (scaffolds, changes, strategies, interaction and socialization) of the collaborative writing revision process. In other words, the study aimed to answer questions regarding what strategies learners use in revising their writing, and how they articulate their membership in this online CoP. 


\section{Research procedure}

The study used three sources of data collection: students' written texts (original drafts and revised or final drafts), their interactional exchanges and comments during the revision activities and their written responses collected from the post-revision written discussion.

A qualitative analysis of the EFL learners' original and last revised drafts and their interactional exchanges was used. Three different taxonomies were adapted from previous studies (Table 4): a taxonomy of the revision strategies or operations, a taxonomy of the revision levels and a taxonomy of the focus or contributions of these revisions to the text (Berbache, 2007; Horne, 2011; Min, 2006).

Table 4

Taxonomies of revision strategies, changes and focus

\begin{tabular}{lll}
\hline $\begin{array}{l}\text { Types of operations/ } \\
\text { strategies }\end{array}$ & $\begin{array}{l}\text { Size \& level of revision } \\
\text { changes }\end{array}$ & Focus of revision changes \\
\hline Additions & Below word level & Mechanics \\
Deletions & Word level & $\begin{array}{l}\text { Language (form \& meaning) } \\
\text { Texture or unity (cohesion within }\end{array}$ \\
Substitutions & Phrase level & $\begin{array}{l}\text { sentences \& coherence among sentences as } \\
\text { relevance of ideas, details, transition }\end{array}$ \\
Permutations & Clause level & $\begin{array}{l}\text { Explicature (concerning explanation } \\
\text { including clarity of topic sentences, ideas, } \\
\text { content }\end{array}$ \\
Distributions & Sentence level & \\
Consolidations & Paragraph level & \\
\hline
\end{tabular}

These taxonomies served as the main codes and sub-codes for the qualitative analysis in this study. Thus, the procedure of analysis was carried out in several steps:

- Reflecting on the students' original drafts, revised or last drafts and their interactional exchanges.

- Comparing and identifying the changes, highlighting and assigning the changes to these codes and sub-codes in terms of strategies, levels of revisions and focus.

- Selecting only the samples that reflect the various categories according to these three taxonomies to report the findings. The unit of analysis used varied from word to sentence while the samples were used in the form of full sentences or paragraphs. The students' responses and interactional comments in the post-revision reflective discussion were also coded into topics which were grouped and identified under categories (Merriam, 1998). The procedure of the analysis was carried out by the researchers and the qualitative assessment of the participants' revision contributions to their written paragraphs was conducted by the instructor as well as the researchers. 


\section{Findings}

\section{What types of writing revision strategies do the EFL learners adopt in revising their paragraphs in writing skill in this CoP?}

The findings of this study are reported based on an analysis of the EFL learners' 91 full revisions and 55 fragmented commentary revisions. Moreover, revision-related commentary exchanges which only reflected learners' explanation, arguments, clarifications, justifications and other aspects related to the revision changes were 221 . However, only sample excerpts are used in this section to present the various themes. The qualitative analysis of the EFL learners' original and revised drafts and their interactional exchanges during the 10 sessions of the collaborative revision activities in this CoP shows that the learners used all these revision strategies at different levels. Table 5 shows 6 sample excerpts illustrating the most commonly identified revision strategies: adding linguistic items (excerpt 1), substituting items by others (excerpt 2), deleting unnecessary items (excerpt 3), re-arranging items (excerpt 4), combining items together (excerpt 5) and separating especially long sentences (excerpt 6). Together, these strategies were used at various levels: below-word, word, phrase, clause, sentence and text levels.

Table 5

Sample excerpts illustrating types of revision strategies

\begin{tabular}{|c|c|c|}
\hline Revision strategies & Samples from the original paragraphs & Samples from the revised paragraphs \\
\hline 1. Additions & I wasn't ready. & I wasn't ready for the exam. (S2) \\
\hline 2. Substitutions & $\begin{array}{l}\text { But it was good because I controlled at } \\
\text { myself. }\end{array}$ & $\begin{array}{l}\text { But it was not harmful because I could } \\
\text { control my body well. (S5) }\end{array}$ \\
\hline 3. Deletions & $\begin{array}{l}\text { Although the first lecture starts at 9:00 } \\
\text { am, but forgot it that totally. }\end{array}$ & $\begin{array}{l}\text { Although the first lecture starts at 9:00 } \\
\text { am, I totally forgot that. (S12) }\end{array}$ \\
\hline 4. Permutations & $\begin{array}{l}\text { At the same time, I was confused } \\
\text { about what should I do. }\end{array}$ & $\begin{array}{l}\text { At the same time, I was confused about } \\
\text { what I should do. (S15) }\end{array}$ \\
\hline 5. Consolidations & $\begin{array}{l}\text { What did I do? I laughed with them } \\
\text { until they stopped. }\end{array}$ & $\begin{array}{l}\text { What I did was that I laughed with } \\
\text { them until they stopped. }(\mathrm{S} 1)\end{array}$ \\
\hline 6. Distributions & $\begin{array}{l}\text { I picked the lightest ball but } \\
\text { unfortunately it got stuck that I had to } \\
\text { pick another one. }\end{array}$ & $\begin{array}{l}\text { I picked the lightest ball but } \\
\text { unfortunately it got stuck. So, I had to } \\
\text { pick another one. (S3) }\end{array}$ \\
\hline
\end{tabular}

* Denotes that italics in all excerpts indicate the changes of revisions made by the learners.

The EFL learners were also involved in group negotiation strategies along with scaffolds to assist peripheral members. Excerpt 6 of the participants' interactional exchanges is evidence of these strategies. The instructor of the community initiated the discussion by asking the learners a question seeking an alternative verb for the phrasal verb "look inside". The learners provided various alternatives and commented on their meaning as a way to provide further explanation and justification of their posted alternatives. As S10 saw the alternative verb "peep", she raised a question about its meaning and immediately got scaffolds and assistance from others. The discussion ended with S2 incorporating this new verb into her revision.

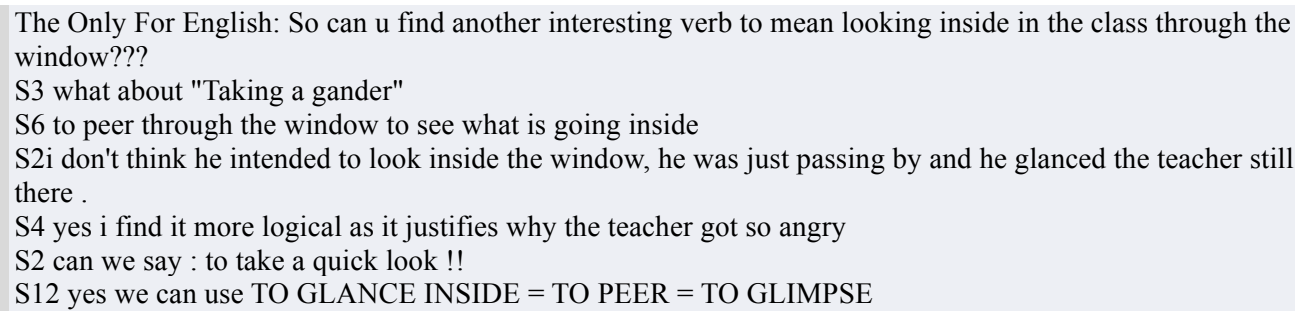




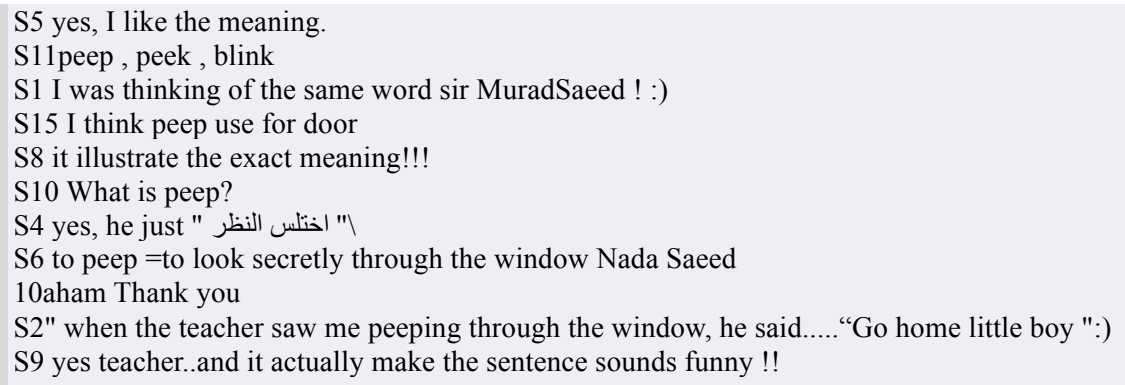

\section{How do these revision strategies contribute to enhancing the EFL learners' paragraph writing in this CoP?}

The findings show that the participants attended to writing mechanics by adding the missing elements, including punctuation in reported speech sentences, commas and full stops at the end of sentences (Table 6). They also substituted words beginning with a small letter initiating a sentence (excerpt 9) and the misspelling of words (excerpt 10).

Table 6

Sample excerpts illustrating contributions of revision strategies to mechanics

\begin{tabular}{lll}
\hline Number & Excerpts from original drafts & Excerpts from revised drafts \\
\hline 7 & $\begin{array}{l}\text { I kept saying Mum take care } \\
\text { Mum take care. }\end{array}$ & I kept saying, "Mom take care. "(S8) \\
& $\begin{array}{l}\text { Although the first lecture starts at } \\
\text { 9:00 am I totally forgot that }\end{array}$ & $\begin{array}{l}\text { Although the first lecture starts at 9:00 am (,) } \\
\text { I totally forgot that (.) (S11) }\end{array}$ \\
9 & $\begin{array}{l}\text { his fame is because of his great } \\
\text { success in the field of medicine. }\end{array}$ & $\begin{array}{l}\text { His fame is because of his great success in } \\
\text { the field of medicine. (S4) }\end{array}$ \\
10 & I controlled myself. & Icontrolled myself. (S6) \\
\hline
\end{tabular}

Deletion of below-word level elements helped the learners to be aware of the importance of these mechanics in terms of readers' interpretation of the meaning of sentences with faulty mechanics. Excerpt 11 shows that the learners' comments focused on the position of the comma after the second phrase in this sentence "During lunch, at the campus cafeteria, they noticed the dirty tables, the overworked cashiers and the exorbitant price for the meal". S1 initiated this by emphasizing the necessary position of the comma between the phrases in this sentence. However, S2 replied to her by raising a question and answering it, but she did not seem to be certain about this as she stated that it is not wrong to put a comma there. S2 seemed to be certain about her answer, and this was supported by S5. Again, S2 elaborated her answer and raised another question regarding whether separating the two phrases would make the meaning clearer. She also seemed to be constantly putting herself in the reader's position to find out what was wrong with the sentence until she finally reached a convincing answer that this comma indicates a pause when it is placed between the two phrases and it seemed unnatural to pause there.

S1 Ok. I am sure that after 'lunch', there should be a 'comma.

S2 You know? I feel that the 1st comma has separated between the time \& the location, but it's not wrong!

S2 I believe that we should remove the 1 st comma in 1 case, when we say "During lunch and at the campus cafeteria "!!

S5 Oh sorry! I didn’t pay attention that the first comma, was after lunch, I think there shouldn't be a comma after lunch $n$ after cashiers!!

S2 I mean, as we are trying to introduce the clause with more than 1 prepositional phrase, wouldn't be better to use a comma between the two phrases to make it clearer and well-organized?

S2 You know? It sounds ear jarring to pause at the 1 st comma, I admit. 
Another aspect that the students attended to was the language (both form and meaning). Table 7 provides samples of the EFL learners' correction of different grammatical errors. This was achieved by adding the necessary missing linguistic elements (excerpt 12), deleting erroneous elements (excerpt 13), substituting more accurate ones (excerpt 14) and re-organizing words in a sentence according to their correct positions (excerpt 15).

Table 7

Sample excerpts illustrating contributions of revision strategies to language form

\begin{tabular}{ccc}
\hline Number & Excerpts from original drafts & Excerpts from revised drafts \\
\hline 12 & Ali was run after me. & Ali was running after me.(S7) \\
13 & When she was getting down in the stairs. & When she was getting down the stairs. (S4) \\
14 & I've never forget that situation. & I've never forgot/forgotten that situation. (S13) \\
15 & At the same time, I was confused about & At the same time, I was confused about what I \\
whould do.(S2)
\end{tabular}

The learners also attended to errors in their peers' revisions of the first drafts of paragraphs through reciprocal scaffolding. Excerpt 16 shows how S8 attracted the attention of S2 to the mistake regarding "was", and S2 replied by explaining the various options of using the structure after the verb "remember", but she forgot to use "was" in the sentence "I remember that I trying" as pointed out by S1.

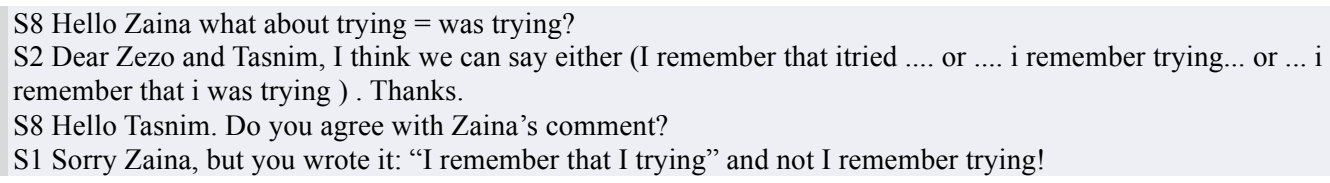

Similarly, these revision strategies contributed to the language meaning. Table 8 shows that the EFL learners attended to more accurate lexical items that express the intended meaning by replacing words and phrases by other alternatives (e.g., replacing the phrase by the verb "avoid" in excerpt 17). In adding various linguistic elements, the participants enhanced the meaning (e.g., expressing abilities in the past using "could" as in excerpt 18) and attended to accurate meaning through substitutions (e.g., accurately describing the scene or event as in excerpt 19).

Table 8

Sample excerpts illustrating contributions of revision strategies to language meaning

\begin{tabular}{ccc}
\hline Number & Excerpts from original drafts & Excerpts from revised drafts \\
\hline 17 & She ran fast to be far from the crowd & She ran fast to avoid the crowd. (S9) \\
18 & I controlled at myself. & I could control myself. (S2) \\
19 & $\begin{array}{c}\text { She was alone and was getting down the } \\
\text { stairs. }\end{array}$ & $\begin{array}{c}\text { She was alone and was descending the stairs. } \\
(\text { S10) }\end{array}$ \\
\hline
\end{tabular}

What is more interesting is that collaborative writing revision activities in this CoP engaged the learners in constantly evaluating the meaning of the lexical alternatives used by them in revising their and their peers' paragraphs. This could be achieved by raising questions seeking assistance and requesting their peers to articulate their agreement or disagreement with these alternatives. Excerpt 20 is a sample of how 
S5 attempted to enhance the meaning by replacing the verb "worry" by "panic" and how she sought peers' assistance to evaluate the meaning of this alternative verb.

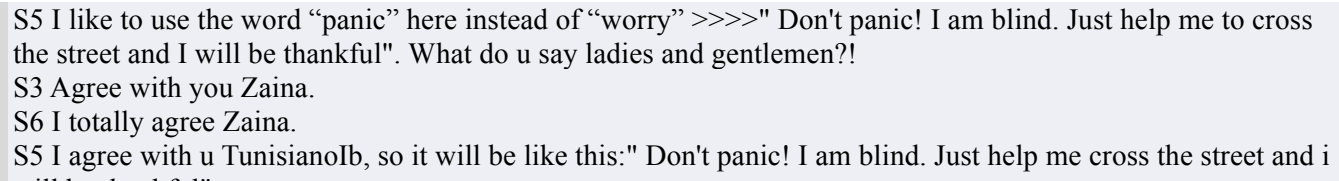

Another way of evaluating the meaning of such alternatives for other linguistic or lexical elements is getting their peers' evaluative assistance immediately without having to ask for it. Excerpt 21 is an illustration of how S6's replacement of "alone" with "lonely" was immediately evaluated by S13, who explained the difference in meaning between the two linguistic elements, and sought S6's opinion about her comment. Therefore, S6 attended to her mistake, which was due to her confusion between the two adjectives in terms of their meaning and agreed with what was commented by S13.

S6 I think we can say "When she was lonely at the centre".

S13 I think alone is more suitable (as it means no one else was there except for her)! Because lonely can be associated more to the feeling. I don't know for sure but that's what I think. What can u say dear?

S6 Sorry. It sounds that I had things missed in my mind .I was really confused between the meaning of lonely and alone. Of course, you are totally right.

Another contribution of these revision strategies, particularly the addition, consolidation, deletion and distribution strategies, is in enhancing the texture or unity of the EFL learners' paragraphs. The participants added words or phrases to establish cohesion among elements at the sentence level. In excerpt 22, S14's comment illustrates the addition of the conjunction "and" to connect the elements in the sentence.

S14 I have just a slight remark to add that we'd better use and to link these : I spoke it very fluently and wrote excellent paragraphs.

Word-level additions assisted the EFL learners to enhance the texture of their paragraphs as they added transitional devices that function as linkers among sentences and achieved coherence among the ideas in the paragraphs. In excerpt 23, S10 added the subordinating conjunction "however" at the beginning of the sentence to link it with the sentence preceding it.

S10 if I have a suggestion here to make the ideas coherent: "If I have occasions to travel abroad, I will be obliged to express my ideas in English. It seems impossible now as I still have difficulties". > > >> However, it seems impossible now as i still have difficulties with my English.

Moreover, the EFL learners achieved the unity of their paragraphs by consolidating two sentences together. Excerpt 24 is an example in which S9 commented on these two sentences by combining them together, thus making the ideas more coherent.

S9Just we need to combine these two sentences: "In this problem, it has nothing to do with the amount of money itself. For one thing, it is not sure that person who borrows much money can return it to his friend in the future". $\gg \gg \gg>$ This problem has nothing to do with the amount of money itself, but it is not certain that the person who borrows much money can return it to his friend in the future.

The findings show that the students deleted irrelevant sentences from their paragraphs as a way of improving the unity of their texts. Excerpt 25 provides a part of the original draft, which contains irrelevant ideas. However, in observing this, S15 and S11 pointed out the irrelevant sentences and justified why they are irrelevant to the topic of the paragraph. Thus, in incorporating such corrective feedback, the revised part of this paragraph became more coherent since all ideas support the main topic of the paragraph. 


\begin{abstract}
First Draft: It is important to provide girls and boys with education in which they get equal opportunities in order to be fair. This means that everyone should have equal access to education. In some countries people only have primary schooling. This allows them to help their parents with their work. Primary schools in Portugal often have two classes, one in the morning and one in the afternoon. Different countries therefore have different systems. Both boys and girls should have the same educational provision. This does not mean that they have to be taught together in the same classroom. Some boys prefer woodwork and some boys prefer cooking. Boys and girls may need to have a separate curriculum. The important thing is that everyone should have the same opportunities.
\end{abstract}

S15 I can see that sentences (3), (5), (6) and (9) are irrelevant to the topic sentence because they don't support it (as the topic sentence is about that both boys and girls should have access to education. It is not talking about the educational system in some countries).

S11 I think here the sentences from 3, 5, $6 \& 9$ are so irreverent since our topic sentence here is different. I mean the mentioned sentences I put don't have a relationship to our topic sentence since the ideas are far from our main topic.

Final Draft: It is important to provide girls and boys with education in which they get equal opportunities in order to be fair. This means that everyone should have equal access to education. This allows them to help their parents with their work. Both boys and girls should have the same educational provision. This does not mean that they have to be taught together in the same classroom. Boys and girls may need to have a separate curriculum. The important thing is that everyone should have the same opportunities.

Finally, the learners enhanced the content of their paragraphs through explicature strategies particularly; providing explanations of topic sentences and the writers' intention, thus contributing to the clarity of the content. In Excerpt 26, initiating a shift in the discussion, S8 attempted to direct his peers' attention to the coherence of the paragraph. However, in responding to his comment, S7 identified the main idea (the topic sentence). The question raised by S8 requesting further clarification of this made S7 further elaborate her previous answer by specifying the main functions of the two introductory sentences of the paragraph. However, S8's comment indicates his insistence on the irrelevance of this sentence, stating the teenagers' negligence of reading. Finally, S2's comment confirmed the explanation and clarification of the functions of these sentences in the paragraph, which made the writer's intention clearer.

S8 I'd like to focus on one point I noticed in paragraph which is the coherence.

S7 Sorry Brother Mohamed, if $u$ give it a close look, you 'll find that paragraph is not about the

and disadvantages of reading but about the causes behind the teenagers` negligence of reading.

S8 What about the topic sentence Tunisiano?

S7 Ok brother: we can divide the introduction likewise: S1 "Reading is the most useful hobby

Thesis statement: S2 "However, it has been neglected for many reasons." $\Rightarrow$ Topic sentence: the rea.. the teenagers` negligence of reading.

S8 Reading is the topic and reasons of negligence seems the controlling idea. The rest of the paragraph should support this idea while the teenagers' negligence of reading is a very different topic.

S2 I agree that the 1st sentence was used as an introduction to the subject. Thus, it doesn't carry the main idea of the paragraph and "Reasons behind teens' negligence of reading" is the topic sentence here as most of the

paragraph's sentences support it.

\title{
How do the EFL peripheral members verbalize their participation and membership in this $\mathrm{CoP}$ in relation to the collaborative writing revision activities via the Facebook?
}

Regarding the third research question, the qualitative analysis of the five EFL learners' comments (only the 5 peripheral members) in the post-revision discussions show that there was a change or difference in who they were in the initial stage of participation in these collaborative revision activities and who they became at the end of this period ( 3 months) as reflected by them. Their comments reflect their peripheral positions within this $\mathrm{CoP}$ at the initial stage of participation. Most of those learners explicitly displayed their feelings of being ignored by others in this CoP. They also reported their feelings of hatred or dislike towards these activities because they were not familiar, did not have an intimate relationship with other members or they were feeling shy due to their English and difficulties in participating in these revision writing activities.

S8: I indeed felt like peripheral because I didn't know anyone. At the beginning I faced a few obstacles; I tried to participate in some discussions but some ignored me. 
S10: At the first time when I joined the only for English learning group, I hated the participation in the revision activities because of my shyness and my English was not that good. I found difficulties in expressing myself and the other members weren't patient with me as I had not any relation with them.

However, reflecting on themselves at the end of this period, the learners commented on how this experience of learning in this online CoP changed them for the better. This change, particularly in regards to their participation in revision activities, is an indicator of their transformation into active positions in this CoP. Some learners commented on developing strong social ties with other members and with the instructors as one way of how they became active participants. This is because such new friends are cooperative and helpful. Moreover, these activities exposed the learners to different cultures.

S13: And what increased my participation in the revision activities in the group is that I found strong social ties among its members and between members and instructors.

S8: I got to know kind friends who helped me a lot in revisions like Tunisiano and Zaina.

S15: Yes indeed, these activities give $u$ the chance to get to know people from different countries and from different cultures and being able to develop friendship with some of them. Some become good friends.

Another indicator of those five learners' realized movement into active participation is the supportive learning environment where they felt motivated to express their ideas. In addition, they commented on the type of teaching instruction or pedagogy used by the instructor in writing revision activities.

S14: During the writing revision activities, the feeling of being a member in Only For English Learning as family rather than a learning group always motivated me to participate".

\begin{abstract}
S8: Then the instructor supported me by saying "Sina is asking." or recalling me to share. In addition, his writing revision activities are so attractive such as the writing paragraphs, correcting sentences, grammar exercises, open discussions etc. Therefore, I started to participate more and more and more actively than before.
\end{abstract}

A few learners commented on developing a sense of autonomy in the language, particularly in writing and communication skills, as they were involved in these writing revision activities.

S10: However, within time I felt like I improved my language that made me able to communicate with the others in a good way.

Regarding the role of Facebook in facilitating the learners' engagement in these writing revision activities, the participants pointed out the features of Facebook that enabled them to benefit from these activities through interaction that might not be achieved in the traditional classroom setting.

S15: Yes, first, the facebook itself has this effect and in a community where learning is the first purpose, one can find it easier to interact and be a part of a team more than when they are applied in a traditional class.

One of the most important features of the Facebook group was commenting on each other's revision of the original written draft.

S8: Most participants even comment on each other's corrected paragraphs and this gives an added value and one extra benefit. It is this way becoming a real collaborative work and more like a writing club or session.

By commenting on each other's work, and assisting each other, learning was perceived by them as more comfortable, easy and helpful.

S13: Moreover, scaffolding is noticed to be more effective cause of the comfort, the ease of use as well as the helping environment the facebook is known for. 


\section{Discussion and implications}

In this study, the EFL learners used various strategies in revising their paragraphs including addition, substitution, deletion, permutation, consolidation and distribution (Figure 5). They were also involved in interaction, scaffolding and negotiation strategies. This particular finding underlies the dynamic nature of writing revision process as emphasized by the social perspective of writing revision as a process (Faigley, 1986; Tompkins, 2008). Moreover, according to Vygotsky's (1978) social learning theory, learners construct their knowledge by interacting and scaffolding each other in a socio-cultural context (Cheng, 2009). This is not new, given similar findings reported in previous classroom studies (Hansen \&Liu, 2005; Mulligan \& Garofalo, 2011) and online studies (Berbache, 2007;Horne, 2011; Kessler, 2009; Woo et al., 2011). Nevertheless, this study can be considered as the first attempt to examine collaborative writing revision among EFL learners in a CoP via a Facebook group. In this study, the learners made multiple revisions of each single paragraph, which included changes at various levels (below-word, word, phrase, clause, sentence and paragraph levels). These changes focused on mechanics and language (forms and meaning), unity and content of their paragraphs.

As found in this study, those five EFL new learners who joined the online CoP and participated in the collaborative writing revision activities felt a sense of periphery in the first stages of their participation but within time, they realized themselves as members of this CoP and contributed to the activities. This was realized through their development of strong social ties with other members and the instructor, building new relationships based on kindness and cooperation, valuing the CoP as an asset-based learning environment and developing autonomy in writing and communication skills within time. These various patterns of socialization and interactions appear to have led to the development of those new or peripheral learners' sense of community and belonging to this group. Thus, the findings highlighted the process of situated learning or learning through socialization as emphasized by Lave and Wenger's (1991) situated learning or CoP theory. "Legitimate peripheral participation" is a situation at which most membership begins (Wenger, 1998 p.11). Furthermore, the findings of this study are consistent with previous research in terms of the importance of creating an asset-based learning environment in educational settings in general (Haberman, 2004; Henson, 2003) and in CoPs in particular (Lieberman \& Wood, 2003; Pearce, 2010) where learners feel less stressed and more motivated and encouraged to participate actively. Despite their geographical remoteness, learners can break down the feeling of marginalization through active establishment and maintenance of online communities (Caplan, 2003).

Based on the findings of the present study, there are also implications for theory, pedagogy and future research. From the theoretical perspective of social development theory and situated learning theory, both these theories emphasized the importance of scaffolds, socialization and interaction in the learning process. Thus, the findings highlight the process and dynamics of situated learning in an online CoP. Another implication for EFL pedagogy and research is that proper utilization of technologies for collaborative writing revision activities among EFL learners may not be well achieved without considering good pedagogical practices. This is because technologies such as SNSs are not only tools by themselves, but can also be turned into interactive learning environments by establishing good pedagogical practices. Therefore, it is obvious from the findings of this study that involving EFL learners in meaningful activities in a CoP via SNSs is one effective means to achieve this in the EFL context. Thus, in this online CoP, writing revision is a dynamic process in which learners with less active participation can be more active and make more effective revisions.

\section{Conclusion}

The present qualitative study explored the dynamics of collaborative writing revision processes among 15 EFL learners as situated in an online CoP via a Facebook group. The findings reveal various strategies used by the participants, including addition, re-ordering, substitution, deletion, scaffolding and negotiation. They could contribute to their written paragraphs in terms of mechanics, language, unity and content. Furthermore, the five peripheral EFL learners described their learning experience in this online $\mathrm{CoP}$ as meaningful and perceived themselves as active members of this $\mathrm{CoP}$ in time.

However, it should be noted that there are several limitations in this study that need to be addressed for future research. The first limitation is the small number of EFL learner participants, and therefore, the 
findings of the present study are not generalizable. The second limitation is that the findings were reported based on the entire group of participants rather than tracing each individual learner's contribution to these paragraphs, since the study was not intended to evaluate the EFL learners' performance in writing. Moreover, the investigation of how the CoP facilitated the EFL learners' participation was exclusive to those peripheral learners. Therefore, further research is still needed to explore collaborative writing revision strategies used by peripheral learners, active learners and core learners. It is also important for future research to identify the major challenges faced by the EFL learners in collaborative revision activities in such a virtual $\mathrm{CoP}$.

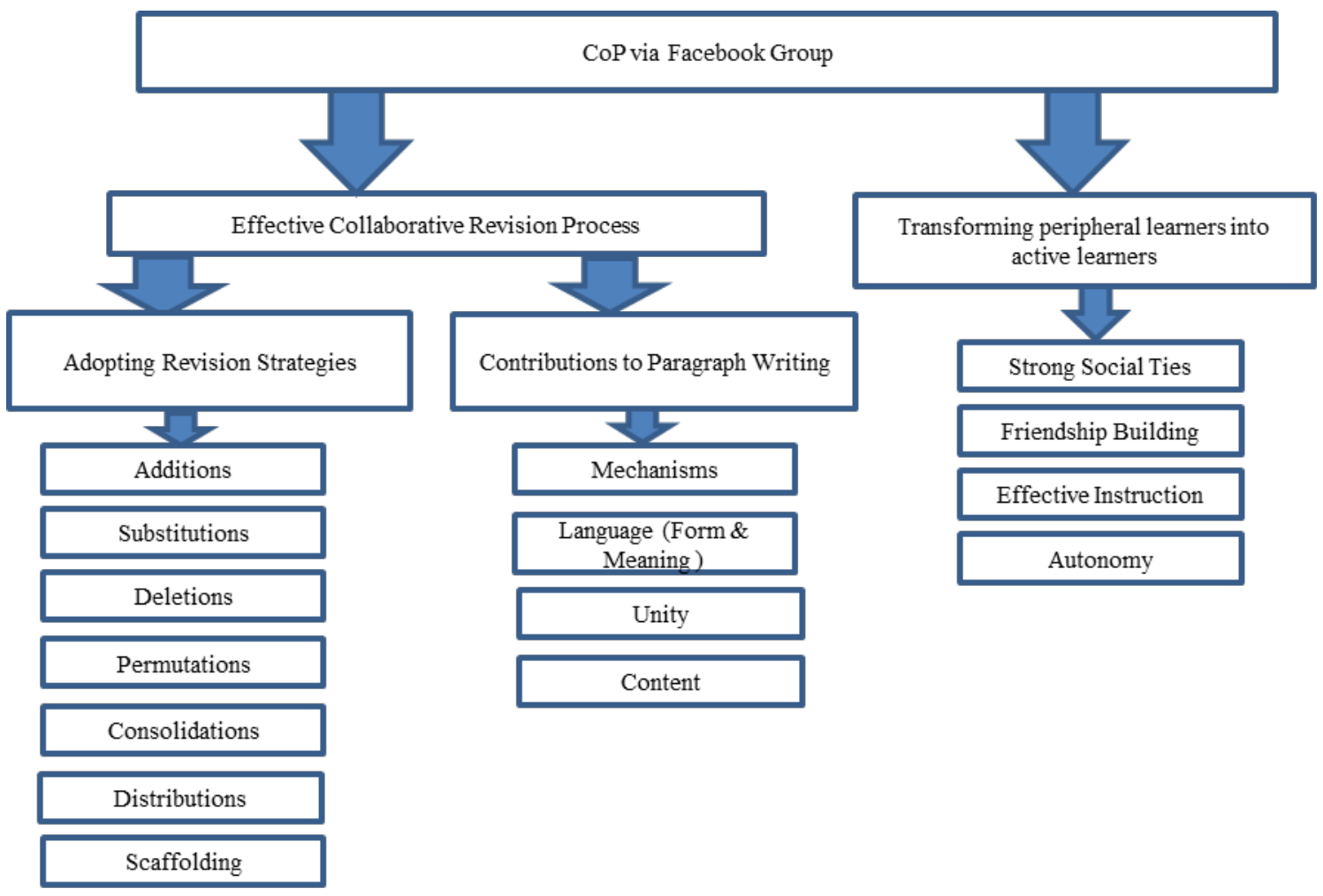

Figure 5. Diagram representation of the major study findings

\section{Acknowledgments}

We would like to thank Universiti Kebangsaan Malaysia (UKM) for the support provided.

\section{References}

Alshumaimeri, Y. (2011). The effects of wikis on foreign language students writing performance.Paper presented at the World Conference on Educational Technology Researches (WCETR-2011), Nicosia / Kyrenia, North Cyprus.Retrieved fromhttp:/www.journals.elsevier.com/procedia-social-andbehavioral-sciences

Berbache, S. (2007).Improving EFL students'writing through trained peer review. Published Thesis for Master in Education. University of Constantine, Algeria.http://bu.umc.edu.dz/md/index.php?lvl=author_see\&id=31699

Bogdan, R., C.,\&Biklen, S. K. (2007). Qualitative research for education: An introduction to theories and methods. Boston, MA: Pearson Education.

Boyd, D. M.,\& Ellison, N. B. (2011). Social network sites: Definition, history and scholarship. Journal of Computer-Mediated Communication,13(1), 210-230. Retrieved from http://onlinelibrary.wiley.com/journal/10.1111/(ISSN)1083-6101 [16th March 2011].

Brooks, S. (2010). Heterogeneous peer response groups: Engaging students in written feedback and 
constructive talk about writing to improve revision skills. Retrieved from ProQuestdatabbase. (1481187)

Caplan, S. E. (2003).Preference for online social interaction. Communication Research,30, 625-48. Retrieved fromhttp://crx.sagepub.com/

Cheng, G. (2009). Using game making pedagogy to facilitate student learning of interactive multimedia.Australasian Journal of Educational Technology, 25(2), 204-220.Retrieved from http://www.ascilite.org.au/ajet/submission/index.php/AJET/index

Creswell, J. W. (2008). Educational research: Planning, conducting and evaluating quantitative and qualitative research(3rd ed.). Chicago, Illinois,USA: Prentice Hall.

Duff, P. (2007). Second language socialization as sociocultural theory: Insights and issues. Language Teaching, 40, 309-319.Retrieved from http://journals.cambridge.org/action/displayJournal?jid=LTA

Duffy, P. (2011). Facebook or Faceblock. In C. McLoughlin\& M. Lee (Eds.), Web 2.0 based e-learning: Applying social informatics for tertiary teaching (pp. 284-300).Hershey, PA: IGI Global.

Elola, I.,\&Oskoz, A. (2010). Collaborative writing: Fostering foreign language and writing conventions development. Language Learning \& Technology, 14(3), 51-71.Retrieved from http://www.llt.msu.edu/index.html

Faigley, L.,\& Witte, S. (1981). Analyzing revision.College Composition and Communication, 32, 400414.. Retrieved from http://www.jstor.org/action/showPublication?journalCode=collcompcomm

Grandzol, C. J.,\& Grandzol, J. R. (2010). Interaction in online courses: More is not always better. Online Journal of Distance Learning Administration,13(2),1-18.Retrieved fromhttp://www.westga.edu/ distance/ojdla/

Haberman, M. (2004). Can STAR teachers create learning communities? Educational Leadership, 61, $52-$ 56.Retrieved fromhttp://www.ascd.org/Default.aspx

Hansen, J.,\& Liu, J. (2005). Guiding principles for effective peer response.English Language Teaching Journal, 59(1), 31-38.Retrieved from http://www.oxfordjournals.org/our_journals/eltj/about.html

Haverback, H. (2009). Facebook: Uncharted territory in a reading education classroom. Reading Today, 27, 1-34. Retrieved from http://www.reading.org/reading-today

Henson, K. T. (2003). Foundations for learner-centered education: A knowledge base. Education, 124, 516.Retrieved fromhttp://connection.ebscohost.com/c/articles/11046646

Horne, S.-A. (2011).An activity-theory analysis of how college students revise after writing center conferences. Published Dissertation for Doctor of Philosophy in Education. University of Iowa,United States.Retrieved from http://ir.uiowa.edu/

Horning, A., \& Becker, A.(Eds.). (2006). Revision: History, theory, and practice. West Lafayette, IN\&Fort Collins, CO: Parlor Press \& WAC Clearinghouse.

Kessler, G. (2009). Student initiated attention to form in autonomous wiki based collaborative writing. Language Learning \& Technology, 13(1), 79-95. Retrieved from http://www.llt.msu.edu/index.html

Kessler, G. Bikowski, D. \& and Boggs, J. (2012). Collaborative writing among second language learners in academic web-based projects.Language Learning \& Technology, 16(1), 91-109. Retrieved from http://www.llt.msu.edu/index.html

Lam, R. (2010). A peer review training workshop: Coaching students to give and evaluate peer feedback. TESL Canada Journal, 27(2), 114-127.Retrieved fromhttp://teslcanadajournal.ca/index.php/tesl/index

Lampe, C., Wohn, D.Y., Vitak, J., Ellison, N.B.,\&Wash, R. (2011). Student use of Facebook for organizing collaborative classroom activities.Computer-Supported Collaborative Learning, 6, 329347.Retrieved fromhttp://ijcscl.org/

Lave, J., \& Wenger, E. (1991). Situated learning: Legitimate peripheral participation. New York, NY: Cambridge University Press.

Liang, M. (2010). Using synchronous online peer response groups in EFL writing: Revision-related discourse. Language Learning \& Technology, 14(1), 45-64. Retrieved from http://www.llt.msu.edu/index.html

Lieberman, A.,\& Wood, D. (2003). Inside the national writing project: Connecting network learning and classroom teaching. New York, NY: Teachers College Press.

Maftoon, P.,\&Ghafoori, N. (2009). A comparative study of the effect of homogeneous and heterogeneous collaborative interaction on the development of EFL learners' writing skill.The Journal of Applied Linguistics, 1(2), 127-158. Retrieved fromhttp://en.journals.sid.ir/JournalList.aspx?ID=13483

Majid, A. H. A., Stapa, H. S.,\&Keong, C., Y. (2012). Scaffolding through the blended approach: Improving the writing process and performance using Facebook. American Journal of Social Issues \& Humanities, 2, 336-342.Retrieved fromhttp://www.ajsih.org/index.php/ajsih/index

McCarthy, J. (2013). Learning in Facebook: First year tertiary student reflections from 2008 to 2011. 
Australasian Journal of Educational Technology, 29(3),337-356.Retrieved from http://www.ascilite.org.au/ajet/submission/index.php/AJET/index

Merriam, S. B. (1998).Qualitative research and case applications in education: Revised and expanded from case study research in education (2nd ed.). San Francisco, CA: Jossey-Bass.

Min, H.T. (2006). The effects of trained peer review on EFL students' revision types and writing quality. Journal of Second Language Writing, 15, 118-141.Retrieved fromhttp://www.sciencedirect.com/science/journal/10603743

Mitchell, K. (2012). A social tool: Why and how ESOL students use Facebook. CALICOJournal, 29, 471493.Retrieved fromhttp://journals.sfu.ca/CALICO/index.php/calico/index

Mulligan, C., \&Garofalo, R. (2011). A collaborative writing approach: Methodology and student assessment. The Language Teacher,35(3). Retrieved from http://jalt-publications.org/tlt

Pearce,T.-R. (2010). The characteristics of a community of practice in a National Writing Project invitational summer institute. Published Dissertation for Doctor of Philosophy in Education. University of North Texas, United States. Retrieved fromhttp://digital.library.unt.edu/explore/collections/UNTETD/

Razak, N. A., Saeed, M., \& Ahmad, Z. (2013). Adopting Social Networking Sites (SNSs) as Interactive Communities among English Foreign Language (EFL) Learners in Writing: Opportunities and Challenges. English Language Teaching, 6(11), 187-198.

Reynolds, T.H.,\& Bonk, C.J. (1996). Facilitating college writers' revisions within a generative-evaluative computerized prompting framework.Computers and Composition, 13(1), 93-108.Retrieved fromhttp://www.sciencedirect.com/science/journal/87554615

Rollinson, P. (2005). Using peer feedback in the ESL writing class.English Language Teaching Journal, 59(1), 23-30.Retrieved fromhttp://www.oxfordjournals.org/our_journals/eltj/about.html

Santoso, A. (2010). Scaffolding in an EFL effective writing class in a hybrid learning community.Published Dissertation for Doctor of Philosophy in Education.Queensland University of Technology, Australia.Retrieved fromhttp://eprints.qut.edu.au/

Shih, R., C. (2011). Can web 2.0 technology assist college students in learning English writing? Integrating Facebook and peer assessment with blended learning.Australasian Journal of Educational Technology,27(5), 829-845. Retrieved from http://www.ascilite.org.au/ajet/submission/index.php/AJET/index

Sommers, N. (1996).Revision strategies of student writers and experienced adult writers. In B. Leeds (Ed.), Writing in a second language: Insights from first and second language teaching and research (pp. 128-136). New York, NY: Longman.

Tompkins, G. E. (2008). Literacy for the 21st century: A balanced approach.(5th ed.). Boston, MA: Allyn\& Bacon.

VanDoorn, G.,\&Eklund, A. (2013). Face to Facebook: Social media and the learning and teaching potential of symmetrical, synchronous communication. Journal of University Teaching \& Learning Practice, 10(1),1-14.Retrieved fromhttp://ro.uow.edu.au/jutlp/

Vygotsky, L. (1978). Mind in society:The development of higher psychological processes. Cambridge, MA: Harvard University Press.

Wasko, M. M.,\&Teigland, R. (2002). The provision of online public goods: Examining social structure in a network of practice. Paper presented at the $23^{\text {rd }}$ International Conference on Information Systems,Barcelona, Spain. Retrieved fromhttp://aisel.aisnet.org/icis2002/?utm_source=aisel.aisnet.org

Wenger, E. (1998).Communities of practice: Learning, meaning, and identity. New York, NY: Cambridge University Press.

Woo, M., Chu, S. K. W., Ho, A.,\& Li, X. (2011). Using a wiki to scaffold primary school students' collaborative writing. Educational Technology and Society, 14(1), 43-54. Retrieved from http://www.ifets.info/

Yu, H.J.,\&Choe, H. (2011). The dynamics of a peer response group in a mixed-level Korean EFL writing class. English Language and Linguistics, 1.187-212. Retrieved fromhttp://www.elsok.org/xe/index.php?mid=english

Yunnus, M. M.,Salehi, H.,Huisun, C.,\& Yen, J. Y. P. (2011). Using Facebook groups in teaching ESL writing. Paper presented at the World Scientific and Engineering Academy and Society on Recent Researches (WSEAS), Penang, Malaysia. Retrieved from http://www.wseas.org/cms.action?id=2741 
Corresponding author: Murad Abdu Saeed, murad.mohammed13@yahoo.com

Australasian Journal of Educational Technology (C) 2014.

Please cite as: Razak, N.A., \& Saeed, M.A. (2014). Collaborative writing revision process among learners of English as a foreign language (EFL) in an online community of practice (CoP). Australasian Journal of Educational Technology, 30(5), 580-599. 